\title{
東京都における冷蔵倉庫のエネルギ一消費害態に関する調査研究 A STUDY ON THE ENERGY CONSUMPTION OF THE REFRIGERATION WAREHOUSE IN TOKYO
}

\author{
柳 澤 聡 子*, 尾島 俊 雄** \\ Satoko YANAGISAWA and Toshio OJIMA
}

\begin{abstract}
A refrigeration warehouse is an important facility which supports eating habits of the citizens as an important point of a cold chain. Since its energy demand is also high, it is necessary to clarify the actual condition of an energy consumption. In this paper, it is illustrated through a field investigation of refrigeration warehouses in Tokyo. As a result, these refrigeration warehouses were classilied into six groups according to the energy intensity. Moreover, the present data of energy intensity is compared to the data of 30 years ago about the same institution. Although most of these groups have increased annual energy consumption, they have decreased annual energy intensity. Meanwhile, the energy intensity of these refrigeration warehouses is on the decline compared to other facilities.
\end{abstract}

Keywords : Energy Intensity, Refrigeration Warehouse, Field Investigation エネルギー消費量原単位, 冷蔵倉庫, 実態調査

1. 序

\section{1 研究目的}

冷蔵倉庫は, 食品低温流通機構（コールドチェーン）の要に位 置付けられる施設であり，都市における豊かな食生活を支えるべ く, 食品の安定供給という重要な役割を担っている。高度経済成長 期以降, 急速な食生活の向上, 多様化に対応して設備投資が進 められ，収容容積は過去 30 年間で約 4 倍 ${ }^{1)}$ に伸びた。また，全 国の泠蔵倉庫のうち, 約 4 割が大都市に立地し, 国内の生産地や 海外から集荷された食品等をストックしている。特に，東京の臨海 部には, 東京都だけでなく首都圈全体の市場機能や物流センター 機能を補完する冷蔵倉庫が集中して立地しており, 今後も需要増 が見込まれている。

一方, 泠藏倉庫におけるエネルギー消費量原単位は, 約 30 年 前の調查社1に扔いて，オフィスビルに扔けるそれを上回っていた。 都市おけるエネルギー消費が増え続ける中，冷蔵倉庫を取り巻く 社会的状況の変化や技術革新を踏まえ，改めてそのエネルギー消 費の現状を明らかにする必要がある。

そこで本研究では，東京都における冷蔵倉庫を対象に実態調 查・分析を行う。冷蔵倉庫の特性や電力使用量の調査から冷蔵倉 庫を分類し，グループごとの実態を把握することを目的とする。

\section{2 研究の方法}

冷蔵倉庫は大きく分けて営業泠蔵倉庫と自家冷蔵倉庫の二つに 分けられる。収容容積でみると, 全国の約 8 割を営業用が占める

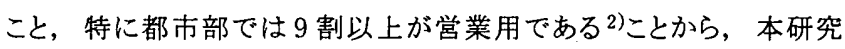
では，営業冷蔵倉庫を対象とした。

はじめに, 東京都に立地する冷蔵倉庫の現状を把握し, 立地別 にみた冷蔵倉庫の特性を明らかにした。

次に, 冷蔵倉庫のエネルギー消費に関する赛態調査を行った。 年間及び月別データについては, 関係団体へのヒアリング調査と各 冷蔵倉庫からの管理日報等の提供を受けた。時刻別データにつ いては, 各冷蔵倉庫の現地にて 24 時間実測調查を行った。これ らのデータを用いて, 冷蔵倉庫の特性とエネルギー消費の関連性 について追求を試みた。冷蔵倉庫の特性の中からエネルギー消費 要因を抽出し，クラスター分析により冷蔵倉庫の分類を行った。

さらに, 年間, 月別, 時刻別の原単位をそれぞれ算出し, 分 類したグループ別に比較・分析を行った。各グループエネルギー 消費パターンを把握し, 冷蔵倉庫におけるエネルギー消費の特徵 を整理した。また, 同一の施設について, 約 30 年前のデータと現 在のデータを比較することで, 冷蔵倉庫におけるエネルギー消費 の量的変化を明らかにした。
* 早稻田大学理厂学総合研究センター 助手・厂俢 ** 早稲由大学理_学部建築学科 教授. 工博.
Research Assoc., Advanced Research Center for Sci. \& Eng., Waseda Univ., M. Eng. Prof., Dept. of Architecture, Faculty of Sci. \& Eng., Waseda Univ., Dr. Eng. 


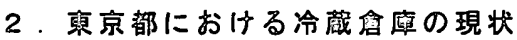

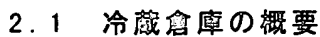

冷蔵倉庫では, 水産物, 畜産物, 農産物, 冷凍食品等の貨物 をその特性に適した温度で保管するため, 別表 1 の通り保管温度 帯を設定している。一般に，C級には冷蔵目的で生鮮食料品を， F級には冷䡒目的で冷凍食品を保管する。庫内では，基本的に入 出庫時の貨物の温度を維持するが，「製氷」や「凍結」など貨物 の温度を庫内で急激に下げる機能もある。これらの機能や保管温 度帯から, 各泠蔵倉庫の主な取扱い貨物やサービス内容が決ま る。また冷蔵倉庫の規模は，一般に収容容積 $\left(\mathrm{m}^{3}\right.$ 又は $\left.\mathrm{t}\right)$ で示さ れる。

冷蔵倉庫の件数や規模は, 各時代のエネルギー問題や経済状 況を反映してきた。戦後の復興期以降, 高度経済成長期を経て, コールドチェーンの中軸産業として急速な擎備桩充が行われきたが, 1970 年代のオイルショックを契機に各倉庫の合理化，減量経営に 切り替えられた。1985 年以降のバブル期には経営状態が好転し, 再び港湾地区を中心に新增設が進んだが，昨今の不況下におい ては，堅調に推移する一方，食品流通の多様化に対応するべくそ の整備が見直されている。

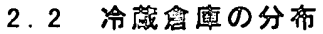

現在東京都には，収容容樌でみて全国の約 $13 \%$ 集中してい る4)。東京都全体で 66 件，そのうち都区部に大部分の 62 件が立 地する。さらに都区部の中では，内陸部に 9 件点在するほかは, 臨海部に 53 件集中している。図1にその分布を示す。

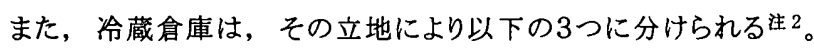
『市場型冷蔵倉庫】

卸売市場内に立地する冷蔵倉庫を指す。市場にもよるが主に水 産物や青果を取り扱っている。市場の時間带に合わせて保管品の 入出庫が行われている。荷主は市場関係者が大半を占める。

『港湾型冷蔵倉庫】

港湾区域及び港湾隣接地域に立地する冷蔵倉庫を指す。主に
水産物や輸入貨物等を取り扱っている。輸入貨物などは一度に大 量に入庫するため，大型で中長期貯蔵に対応した冷蔵倉庫が多 い。また最近，配送機能を強化した流通系の泠蔵倉庫も見られる。

【内陸型冷蔵倉庫】

内、陸に立地する冷蔵倉庫を指す。流通系の泠蔵倉庫が多く，各 店舗に配送するための中継ポイントにあたるので，配送機能が充 実している。

以下，東京都に招ける冷蔵倉庫 66 件を対象とし，表 1 に示す項 目について実態調査を行った。このうち 52 件について有効なデー 夕を得られた。各データの立地別を表 2 に示す。以下，立地別に みた冷蔵倉庫の特性について分析を行う。なお，当初の調㚗では 建物の断熱性能に関する項目が含まれていたが，有効なデータが 十分に得られなかったため，以下の分析結果からは除外している。

別表 1 冷䈗蒼廟の保管温度带 ${ }^{3)}$

\begin{tabular}{|c|c|c|c|}
\hline C3級 & $+10^{\circ} \mathrm{C}$ 以下 $-2^{\circ} \mathrm{C}$ 走满 & F1级 & $-20^{\circ} \mathrm{C}$ 以下 $-30^{\circ} \mathrm{C}$ 末渾 \\
\hline C2級 & $-2^{\circ} \mathrm{C}$ 以下 $-10^{\circ} \mathrm{C}$ 满 & F2級 & $-30^{\circ} \mathrm{C} \approx$ \\
\hline C1級 & $-10^{\circ} \mathrm{C}$ 以下 $-20^{\circ} \mathrm{C}$ 圭潈 & F3級 & $-40^{\circ} \mathrm{C}$ 満 $-50^{\circ} \mathrm{C}$ 以下 \\
\hline & & & \\
\hline
\end{tabular}

表 1 調楂項目

\begin{tabular}{|c|c|c|}
\hline & 收容能力 & 收容容福 $\left(\mathrm{m}^{3}\right)$ \\
\hline 2 & 保管温廢带別呮容能力 & 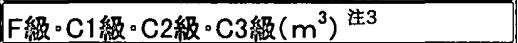 \\
\hline 3 & 酎永能力注4 & $(t /$ 日) \\
\hline 4 & 渺結能力注5 & $(t /$ 日) \\
\hline 5 & 竣工年 & （年） \\
\hline 6 & 霆うの需要調整契約注 6 & $\begin{array}{l}\text { ピーク時間調整契約·産業用蓄熱調整契綡 } \\
\text { 時間篣別調整契約。李節別時間带別契約 }\end{array}$ \\
\hline & 契約冤力 & (kW) \\
\hline
\end{tabular}

表 2 冷籍會嗵データの立地別注7

\begin{tabular}{|c|c|c|}
\hline 立地別 & 件敨 & 冷蔵倉庭No. \\
\hline 市場型 & 5 件 & No.6 $\sim 10$ \\
\hline 港湾型 & 38晔 & No.11 54 (27, 28, 31, 32, 33, 49除く) \\
\hline 队陸型 & 9件 & No.55 66 $(57,58,65$ 除く $)$ \\
\hline
\end{tabular}

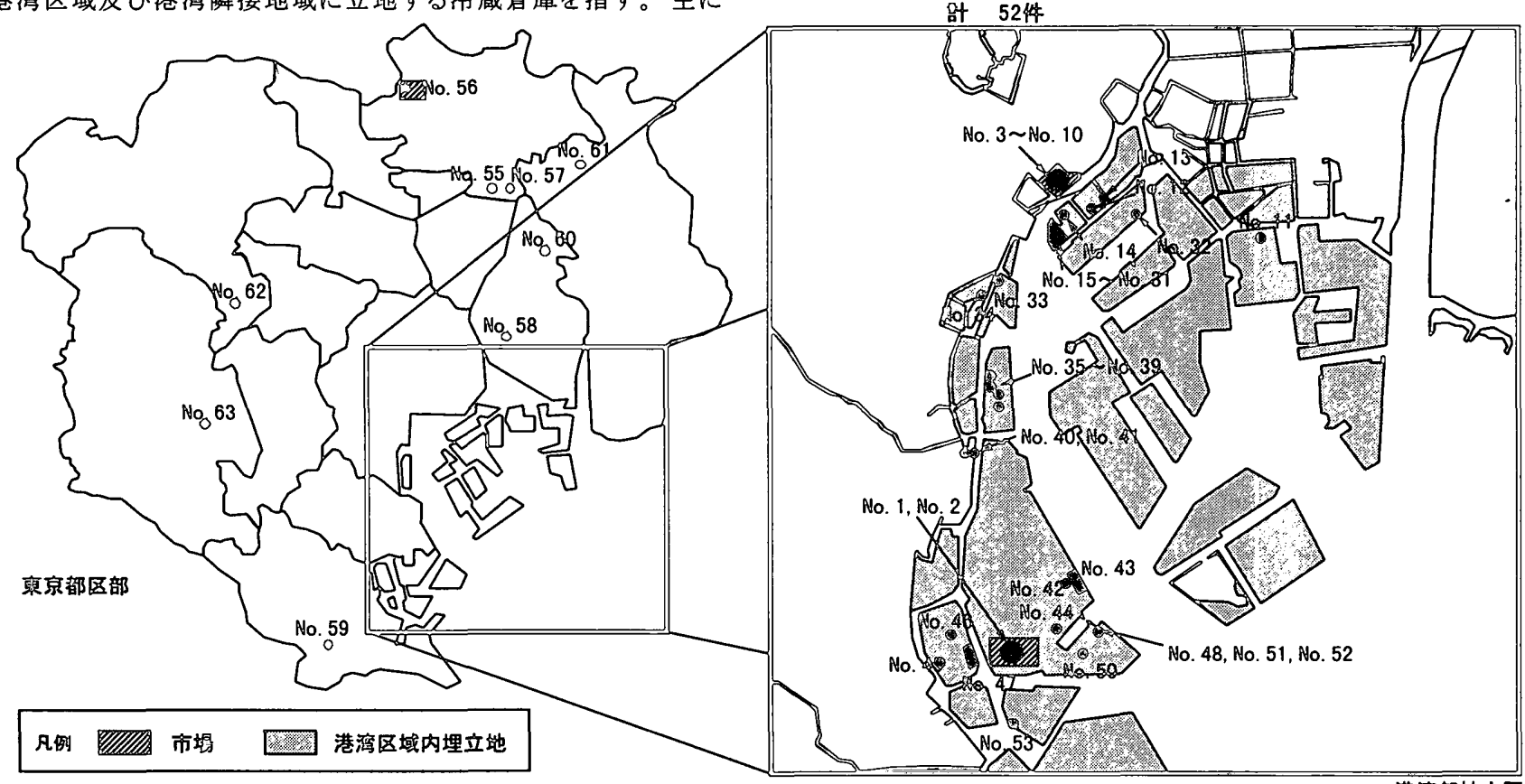

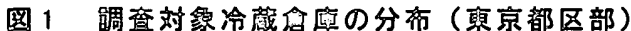




\section{3 立地別にみた冷蔵倉庫の特性}

$7 つ の$ 調査項目（表1）に対応して，立地別の特性を整理した。 収容能力をみると（図 2)，市場型および内陸型は，収用能力 $10,000 \mathrm{~m}^{3}$ 前後に集中している。港湾型は $20,000 \mathrm{~m}^{3}$ 以上が約 9 割を占め, 全国平均 ${ }^{9}$ の $14,595 \mathrm{~m}^{3}$ と比べても, 大型の冷蔵倉庫 が多いといえる。

保管温度帯をみると（図3），いずれもF級が全収容能力の $70 \%$ 以上を占めていることがわかる。特に港湾型は顕著で，F級が全 体の $95 \%$ を占める。また，市場型は他に比べC級の割合が約 25 \%と大きい。

製水能力をみると（図 4)，市場型および港湾型は，製氷機能を もたない冷蔵倉庫が多いことがわかる。一方，内陸型には100t/ 日を超える製隶能力を持つものも存在する。

凍結能力をみると（図5), いずれも凍結機能を持つ冷蔵倉庫 は，3 割に満たない。港湾型は凍結機能が比較的多く, 30t/日 以上の凍結能力を持つものもある。凍結機能のない冷蔵倉庫が多 い背景には，保冷コンテナや冷凍車等の輸送機器能力の向上に より，入庫後に再凍結をする必要がなくなった為と考えられる。 築年数をみると（図6），全体的に築 30 年以上の冷蔵倉庫が多
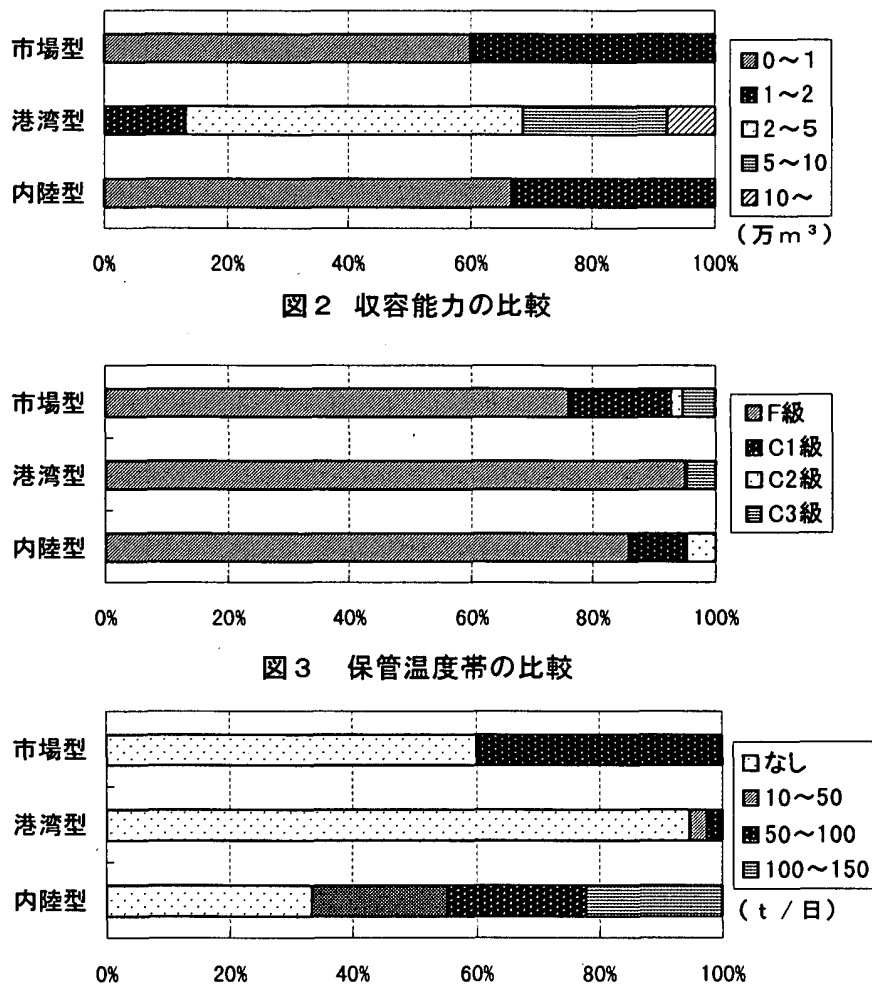

図 4 製水能力の比較

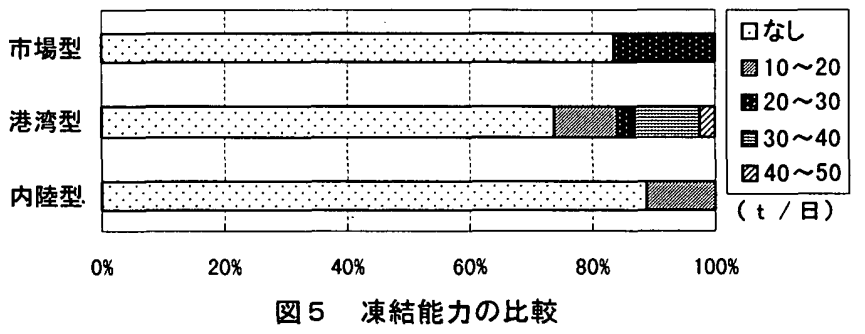

い。特に市場型は，築 $40 \sim 50$ 年が約 8 割を占める。港湾型は, バブル経済期の新設分があるので他に比べて分散している。内陸 型は市場型と同様に築 40 年以上が多く，築 $50 \sim 55$ 年のものが 存在するなど施設の老朽化が問題であると考えられる。

契約電力をみると（図7），契約電力が $500 \mathrm{~kW}$ 末満の椧蔵倉庫 が大半を占めている。 $500 \mathrm{~kW}$ を境に契約料金が上がるためこれを 上限に契約電力が抑えられていると考えられるが，港湾型の中に は，契約電力が $5,000 \mathrm{~kW}$ 前後の大型冷蔵倉庫もみられる。

電力需要調整契約の加入状況をみると（図8），港湾型掞よび内 陸型は大半が加入しているのに対し，市場型はいずれも加入して いなかった。市場型は卸売市場に合わせて営業するので，入出庫 ピーク時の蓄熱など契約条件を満たすのが難しいためと考えられる。 一方，港湾型では，約 $95 \%$ が加入しており，約 $40 \%$ が複数の契 約に同時加入している。

以上のように，泠蔵倉庫は立地別に特性が分かれる。そのエネ ルギー消費実態を明らかにする為には，これらの特性を踏まえて分 析する必要がある。そこで以下においては，同じ 52 件の冷蔵倉 庫を対象に, これらの特性と各泠蔵倉庫の電力使用量の関係から エネルギー消費要因を明らかにし，冷蔵倉庫の分類を行う。
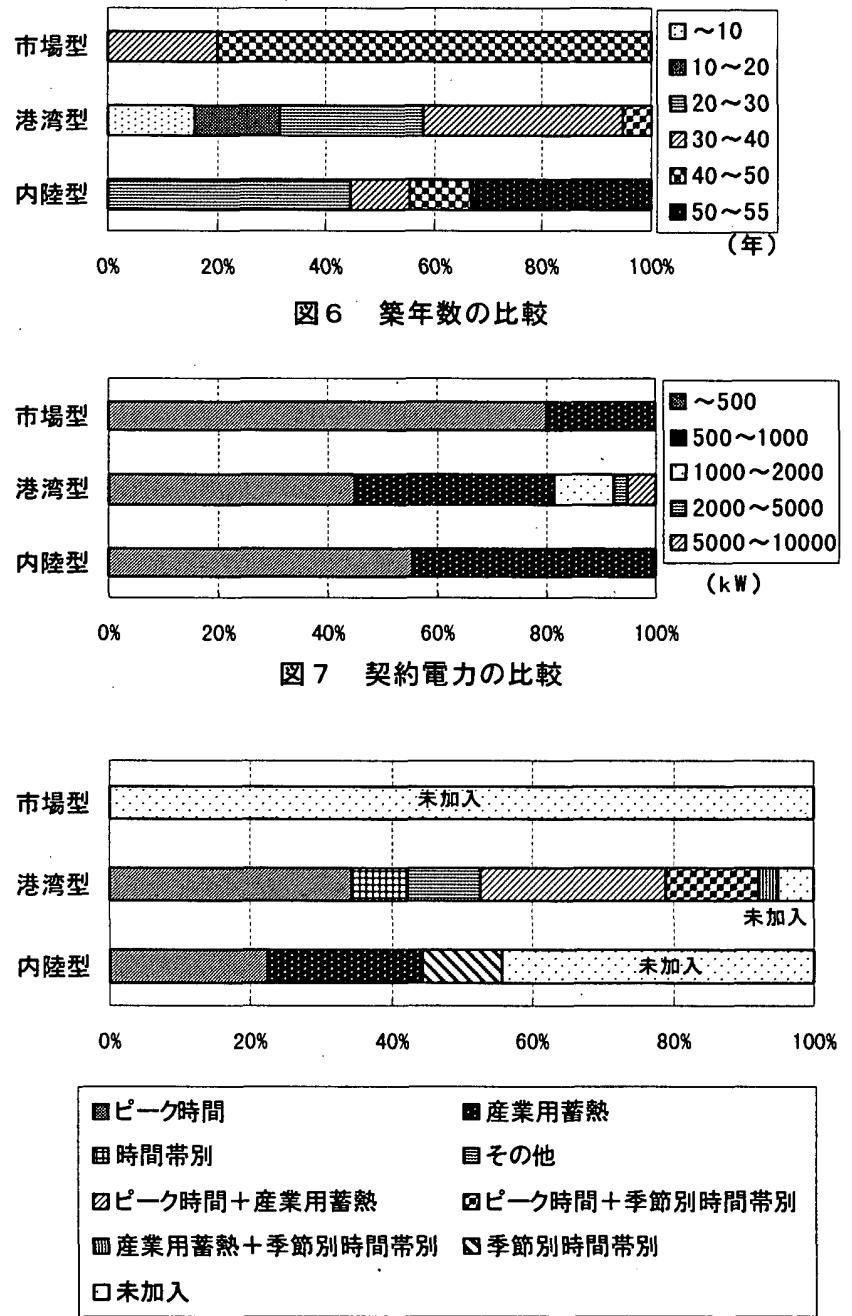

図 8 需要調整契約加入状況の比較 


\section{3.エネルギー消費要因による冷成倉廟の分額}

分類にあたり，泠蔵倉庫の電力使用量原単位 $\left(\mathrm{kWh} / \mathrm{m}^{3}\right)$ 注 8 を 算出した。算出に用いたデータの計測時期を表3に示す。なお， 一般に原単位の算出には単位延床面積 $\left(\mathrm{m}^{2}\right)$ を用いるが，冷蔵 倉庫の規模は収容能力を表す有効容積 $\left(\mathrm{m}^{3}\right)$ で示されるため, こ こでは単位容積あたりで求めた。

\section{1 分影方法}

まず，偏相関分析より，各冷蔵倉庫の年間電力使用量原単位と 関係性が高い調査項目を抽出する。次に抽出された調査項目をも とにクラスター分析を行い，エネルギー消費特性を考虑した原単位 グループに分類する。

\section{2 偏相関係数の算出}

図9に示す通り，52 件の冷蔵倉庫を対象に 14 個の調査項目と 年間電力使用量原単位との間で偏相関係数の算出を行った。その 結果, 偏相関係数士 0.15 以上の高い関係性を示した項目として, 立地 - 収容能力 - 製氷能力 - 契約電力 - 産業用蓄熱調整契約 - 時 間帯別調整契約の計6項目を抽出した。

\section{3 クラスター分析}

上記の6項目を用いてクラスター分析を行った。最終的に，立 地 - 収容能力 ·製氷能力 ・産業用蓄熱調整契約の計 4 項目を用 いた際に最適となり，(1)〜 (9)の 9 個のグループに分かれた。図 10 にクラスター分析の結果を示す。

\section{4 原単位グループの作成}

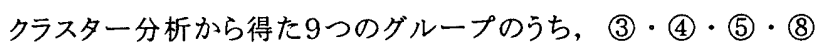
グループは年間電力使用量原単位が類似しているため, グループ としてひとつにまとめた。その結果, $\mathrm{R} 1 \cdot \mathrm{R} 2 \cdot \mathrm{R} 3 \cdot \mathrm{R} 4 \cdot \mathrm{R} 5 \cdot \mathrm{R} 6$ の 計6つの原単位グループに分かれた。各グループの件数, 立地及 び特徵を表4に示す。市場, 港湾, 内陸の立地別に製办の有無 や収容能力の規模など特徵が表れている。以下，このグループ別 に分析を行う。

\section{4.冷藏倉庫のエネルギー消费原単位}

\section{1 年間電力犆用量原単位}

グループごとの年間電力使用量原単位を図 11 に示す。これによ るとR4 が最も小さく，最大值を示す R 5 の約 1 ／ 10 に相当する。 図2に示す通り，港湾型は他に比べて収容能力が大きいが， R3， R4 の值から年間電力使用量原単位は抑えられている。さらに, R4 の収容能力は R3 の 2 倍以上であるが，年間電力使用量原単位は 約6割に抑えられていることから，エネルギー消費が冷蔵倉庫の規

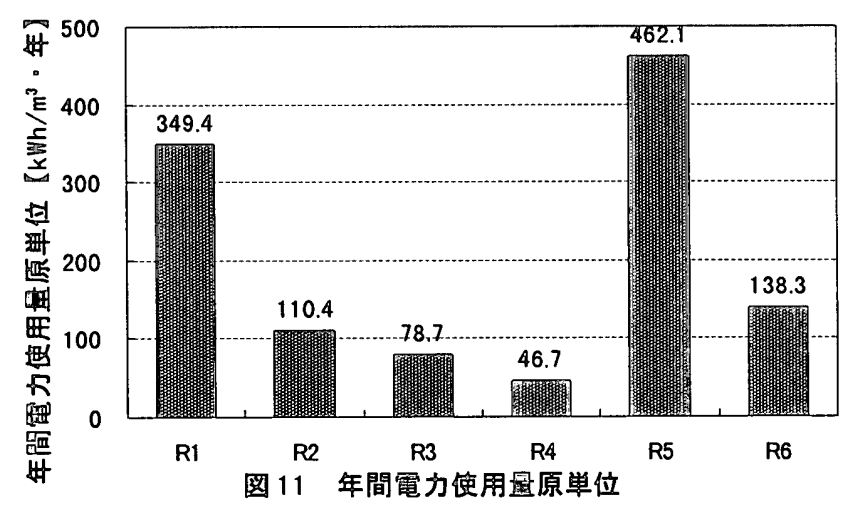

変 3 電力使用瘦原単位の䇠出に用いたデータの計测時期

\begin{tabular}{|c|c|c|c|c|}
\hline 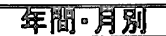 & \multicolumn{4}{|c|}{ 眭㱀别 } \\
\hline 全湕物 & 建物別 & 夏期 & 中間期 & 弪期 \\
\hline \multirow{12}{*}{$\begin{array}{c}\text { 1999年4月～ } \\
\text { 2000年3月 } \\
\text { 。 }\end{array}$} & No.6 & $1999 / 7 / 30$ & $1999 / 4 / 22$ & $2000 / 2 / 3$ \\
\hline & No.7 & $2000 / 7 / 24$ & $2000 / 10 / 29$ & $2000 / 1 / 6$ \\
\hline & No.8 & $2000 / 9 / 13 \sim 9 / 14$ & - & - \\
\hline & No.21 & $2000 / 8 / 31$ & $2000 / 4 / 7$ & $2000 / 2 / 1$ \\
\hline & No.22 & $2000 / 9 / 13 \sim 9 / 14$ & - & - \\
\hline & No.23 & $2000 / 9 / 13 \sim 9 / 14$ & E & $=$ \\
\hline & No.24 & $2000 / 8 / 31$ & $2000 / 4 / 7$ & $2000 / 2 / 1$ \\
\hline & No.34 & $2000 / 8 / 1$ & $2000 / 4 / 7$ & $2000 / 2 / 1$ \\
\hline & No.37 & $2000 / 8 / 10$ & $1999 / 11 / 9$ & $2000 / 2 / 8$ \\
\hline & No.42 & $2000 / 8 / 29$ & $2000 / 4 / 11$ & $2000 / 2 / 10$ \\
\hline & No. 45 & & $2000 / 4 / 1$ & - \\
\hline & No.54 & $2000 / 8 / 1$ & $2000 / 4 / 1$ & $2000 / 2 / 1$ \\
\hline
\end{tabular}

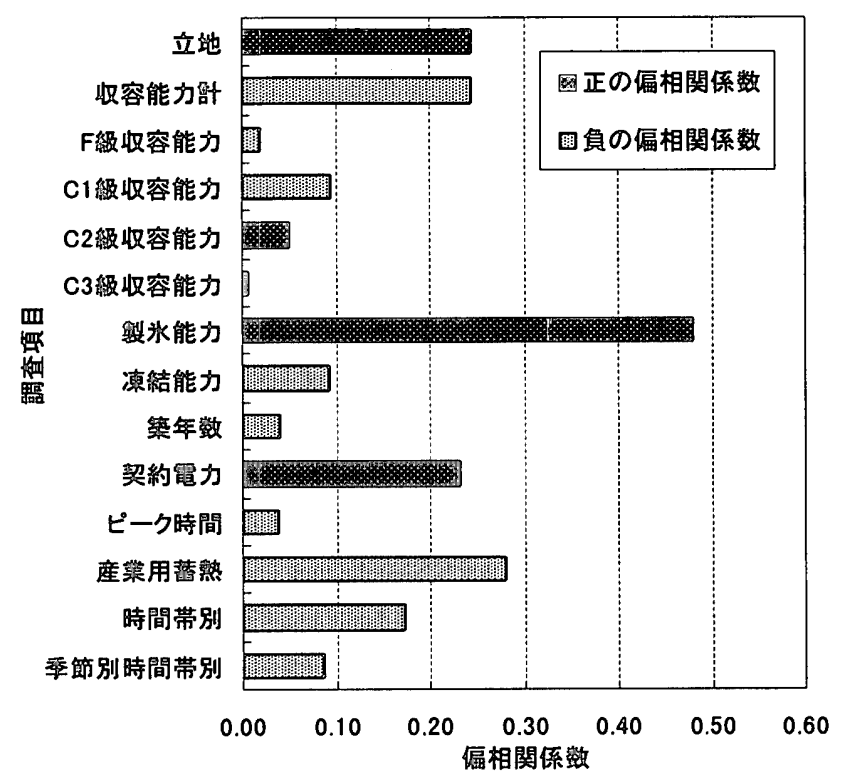

图 9 調望項目ごとの偏相関係数

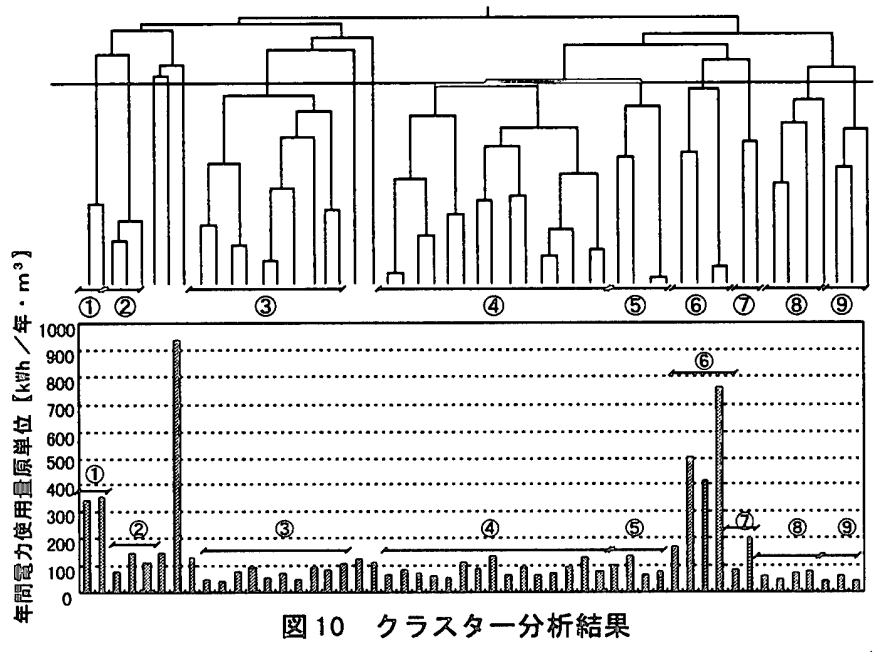

漖 4 原単位グループ

\begin{tabular}{|c|c|c|c|c|}
\hline グループ & クラスター分整 & 华整 & 立站 & 圱徵 \\
\hline R1 & (1) & 2 & 市場 & 䈣永あり \\
\hline R2 & (2) & 3 & 市場 & 裂水なし \\
\hline R 3 & (3), (4), (5), (8) & 35 & 港湾 & 怾容能力 10 万 $\mathrm{m}^{3}$ 未満 \\
\hline $\mathbf{R} Q$ & (9) & 3 & 港湾 & 収容能力 20 万 $\mathrm{m}^{3}$ 以上，葪水なし \\
\hline R5 & (6) & 6 & 内陸 & 裂永あり \\
\hline R 6 & (7) & 3 & 内陸 & 製永なし \\
\hline
\end{tabular}


模に反比例していると考えられる。一方，図2によると市場型と内陸 型はほぼ同規模であるが， R1，R2に比べてR5，R6 は大きい。 図7に示す通り，内陸型は市場型に比べ契約電力が大きいことが 要因として指摘できる。また， R1，R2 は，それぞれ R5，R6に 比較して, 年間電力使用量が 3 倍以上高くなっており, 製水能力 の有無が要因であると考えられる。

\section{2 月別電力使用量原単位}

グループごとの月別電力使用量原単位を図 12 ，表5に示す。 $R 1$ およびR5 グループは，他に比べ変動幅が大きく，最大值となる8 9月は，最小值となる 2 ・3月の約 2 倍に変動する。これは製氷を 行うため，季節変動の影響に加え夏場の製氷需要の影響を受ける のが要因と考えられる。他のグループも変動幅は小さいが $8 \cdot 9$ 月 にピークを迎えており，外気温の変動に影響を受けていることがわ かる。

\section{3 時刻別電力使用量原単位}

\section{3.1 電力需要調整契約を考虑した分析}

前述の通り，冷蔵倉庫では，電力需要調整契約に加入している ケースがあり，時刻別の電力使用量はこの契約条件に従い制御さ れている。よって時刻別については，これまでの原単位グループ 内で需要調整契約加入状況を考慮したパターン分類を使う。表 6 に パターン分類の概要を示す。以下，時刻別の電力使用量データが 入手できた 11 件を対象に時刻別の電力消費パターンについて分析 を行う。

\section{3.2 時刻別電力使用量原単位のパターン別比較}

パターン別の時刻別電力使用量原単位 (時刻別比率) を図 13 〜図 17 及び表 7 に示し，夏期，中間期，冬期泩 9 に分けて特性を 比較する。

A， B パターンは市場に立地するが， A に比べ B パターンは変 動幅が大きい。A パターンは市場が開く深夜から早朝にかけて市 場内の水需要に対応するのに対し， $\mathrm{B}$ パターンは開市前後に氷以 外の冷蔵需要に対応するためと考えられる。また，A， B パターン とも，日中午後に変動が小さいのは，閉市時間帯にあたるためと考 えられる。一方，港湾地域に立地する C, D， E パターンは，い

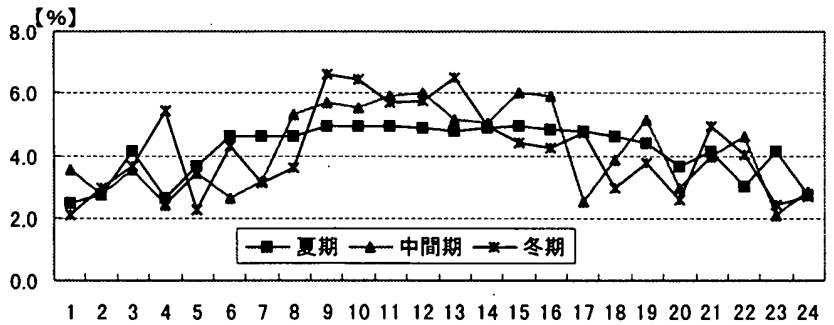

図 13 時刻別電力使用量原単位（Aパターン）

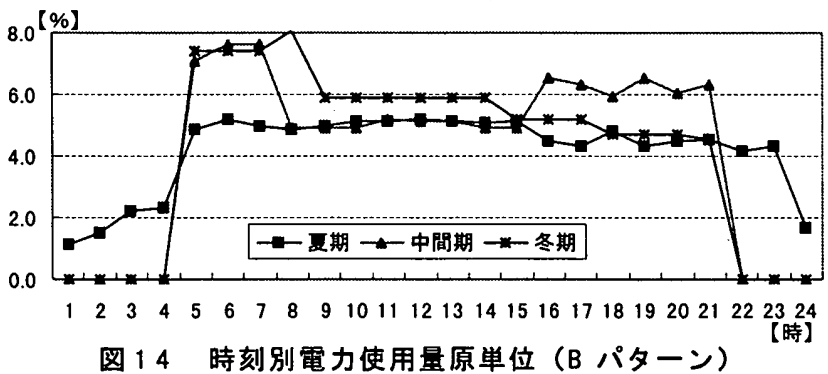

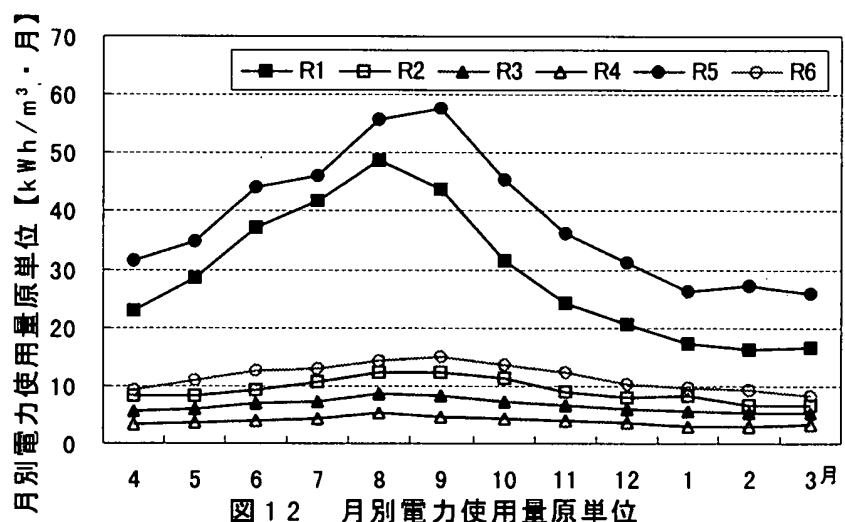

表 5 月別電力使用量原単位【単位: kWh/m³ . 月】

\begin{tabular}{|r|r|r|r|r|r|r|}
\hline \multicolumn{1}{|c|}{} & \multicolumn{1}{c|}{$\mathrm{R} 1$} & \multicolumn{1}{c|}{$\mathrm{R} 2$} & $\mathrm{R} 3$ & $\mathrm{R} 4$ & $\mathrm{R} 5$ & $\mathrm{R} 6$ \\
\hline \hline 4月 & 23.0 & 8.2 & 5.6 & 3.4 & 31.6 & 9.4 \\
\hline 5月 & 28.5 & 8.1 & 6.1 & 3.8 & 34.8 & 10.8 \\
\hline 6月 & 37.2 & 9.3 & 6.8 & 4.1 & 44.2 & 12.7 \\
\hline 7月 & 41.9 & 10.7 & 7.4 & 4.5 & 46.1 & 13.0 \\
\hline 8 月 & 48.7 & 12.1 & 8.5 & 5.2 & 55.6 & 14.3 \\
\hline 9 月 & 43.7 & 12.3 & 8.3 & 4.7 & 57.7 & 15.0 \\
\hline 10月 & 31.5 & 11.2 & 7.4 & 4.2 & 45.3 & 13.6 \\
\hline 11月 & 24.3 & 9.1 & 6.5 & 3.9 & 36.1 & 12.2 \\
\hline 12月 & 20.4 & 8.0 & 6.1 & 3.6 & 31.1 & 10.3 \\
\hline 1月 & 17.2 & 8.3 & 5.5 & 2.9 & 26.4 & 9.5 \\
\hline 2月 & 16.2 & 6.7 & 5.2 & 3.1 & 27.3 & 9.3 \\
\hline 3月 & 16.7 & 6.6 & 5.2 & 3.2 & 26.0 & 8.1 \\
\hline
\end{tabular}

表 6 パターン分類

\begin{tabular}{|c|l|c|l|}
\hline グループ & \multicolumn{1}{|c|}{ 電力需要調整契約 } & パターン & \multicolumn{1}{|c|}{ 冷蔵倉庫No. } \\
\hline \hline R 1 & 末加入 & A & No. 7 \\
\hline R 2 & 末加入 & B & No. 6.8 \\
\hline \multirow{3}{*}{ R 3 } & ピーク時間 & C & No. 21 \\
\cline { 2 - 4 } & ピーク時間+産業用蓄熱 & D & No. 22, 23, 34,42,45 \\
\cline { 2 - 5 } & ピーク時間+季節別時間帯別 & E & No. 24, 54 \\
\hline
\end{tabular}
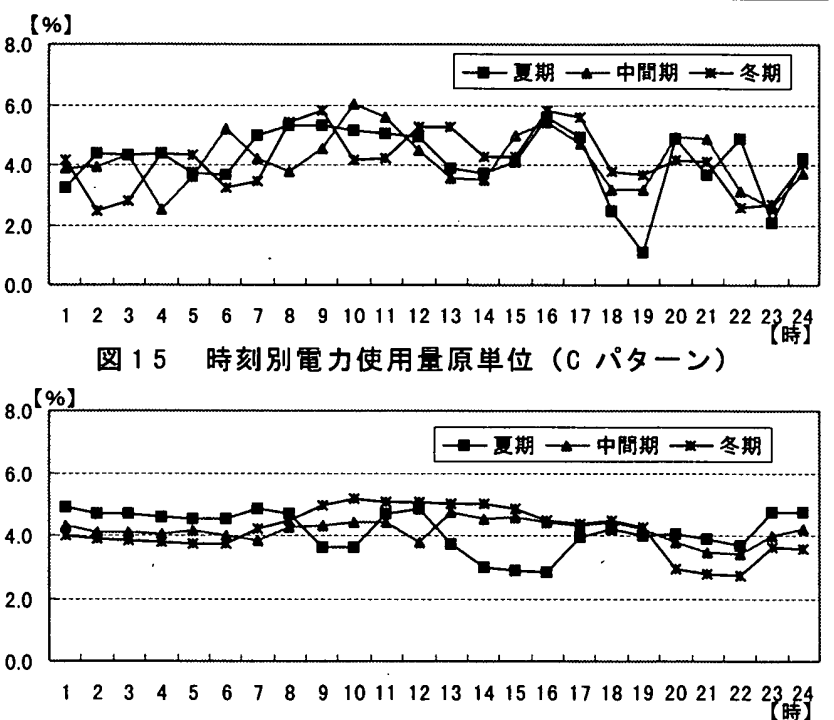

図 16 時刻別電力使用量原単位（Dパターン）

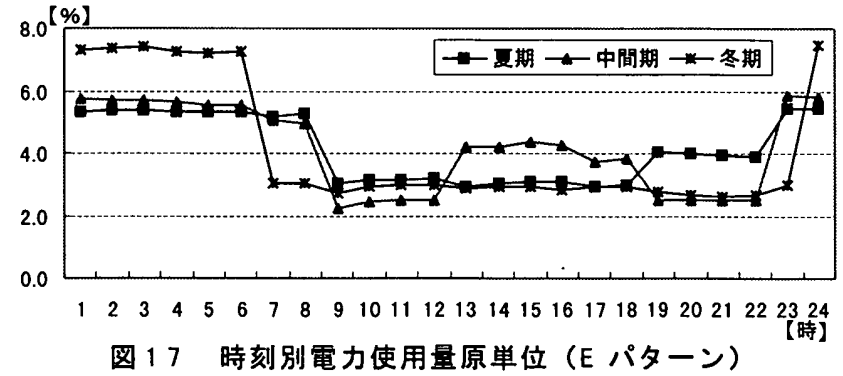


表 7 時刻別電力使用量原単位 【単位 : \%】

\begin{tabular}{|c|c|c|c|c|c|c|c|c|c|c|c|c|c|c|c|}
\hline \multirow[b]{2}{*}{ 時刻 } & \multicolumn{3}{|c|}{ Aパターン } & \multicolumn{3}{|c|}{ Bパターン } & \multicolumn{3}{|c|}{ Cパターン } & \multicolumn{3}{|c|}{ Dパターン } & \multicolumn{3}{|c|}{ Eパターン } \\
\hline & 夏期 & 中間期 & 冬期 & 夏期 & 中間期 & 冬期 & 夏期 & 中間期 & 冬期 & 夏期 & 中間期 & 冬期 & 夏期 & 中間期 & 冬期 \\
\hline 1 & 2.49 & 3.54 & 2.07 & 1.14 & 0.00 & 0.00 & 3.23 & 3.90 & 4.18 & 4.88 & 4.32 & 4.02 & 5.32 & 5.75 & 7.29 \\
\hline 2 & 2.74 & 2.75 & 2.94 & 1.49 & 0.00 & 0.00 & 4.38 & 3.95 & 2.46 & 4.71 & 4.12 & 3.87 & 5.40 & 5.73 & 7.35 \\
\hline 3 & 4.13 & 3.55 & 3.64 & 2.21 & 0.00 & 0.00 & 4.33 & 4.34 & 2.82 & 4.71 & 4.08 & 3.81 & 5.38 & 5.70 & 7.41 \\
\hline 4 & 2.61 & 2.44 & 5.44 & 2.33 & 0.00 & 0.00 & 4.41 & 2.50 & 4.36 & 4.57 & 4.08 & 3.79 & 5.32 & 5.63 & 7.27 \\
\hline 5 & 3.64 & 3.42 & 2.24 & 4.88 & 7.09 & 7.40 & 3.74 & 3.60 & 4.34 & 4.56 & 4.15 & 3.72 & 5.31 & 5.52 & 7.19 \\
\hline 6 & 4.61 & 2.61 & 4.30 & 5.20 & 7.61 & 7.40 & 3.68 & 5.21 & 3.21 & 4.55 & 4.02 & 3.75 & 5.32 & 5.55 & 7.27 \\
\hline 7 & 4.60 & 3.18 & 3.13 & 5.00 & 7.61 & 7.40 & 4.98 & 4.24 & 3.47 & 4.86 & 3.86 & 4.23 & 5.18 & 5.06 & 3.01 \\
\hline 8 & 4.64 & 5.29 & 3.62 & 4.88 & 4.90 & 8.04 & 5.30 & 3.79 & 5.41 & 4.69 & 4.26 & 4.46 & 5.25 & 4.95 & 3.06 \\
\hline 10 & 4.92 & 5.52 & 6.43 & 5.12 & 4.90 & 5.92 & 5.15 & 6.02 & 4.16 & 3.64 & 4.44 & 5.17 & 3.13 & 2.46 & 2.91 \\
\hline 11 & 4.93 & 5.91 & 5.67 & 5.12 & 5.19 & 5.92 & 5.02 & 5.60 & 4.21 & 4.68 & 4.42 & 5.07 & 3.14 & 2.52 & 2.96 \\
\hline 12 & 4.87 & 5.99 & 5.73 & 5.18 & 5.13 & 5.92 & 4.92 & 4.52 & 5.28 & 4.87 & 3.78 & 5.07 & 3.21 & 2.50 & 2.99 \\
\hline 13 & 4.76 & 5.13 & 6.48 & 5.16 & 5.13 & 5.92 & 3.87 & 3.55 & 5.24 & 3.75 & 4.74 & 5.01 & 2.96 & 4.21 & 2.89 \\
\hline 14 & 4.89 & 5.05 & 4.93 & 5.10 & 4.90 & 5.92 & 3.74 & 3.53 & 4.27 & 2.96 & 4.52 & 4.99 & 3.04 & 4.23 & 2.91 \\
\hline 15 & 4.93 & 6.02 & 4.41 & 5.14 & 4.90 & 5.21 & 4.13 & 4.96 & 4.29 & 2.86 & 4.60 & 4.83 & 3.11 & 4.37 & 2.92 \\
\hline 16 & 4.83 & 5.92 & 4.24 & 4.50 & 6.52 & 5.21 & 5.59 & 5.45 & 5.82 & 2.85 & 4.41 & 4.48 & 3.12 & 4.29 & 2.85 \\
\hline 17 & 4.77 & 2.51 & 4.74 & 4.32 & 6.34 & 5.21 & 4.93 & 4.72 & 5.59 & 3.94 & 4.32 & 4.38 & 2.94 & 3.74 & 2.92 \\
\hline 18 & 4.64 & 3.86 & 2.94 & 4.80 & 5.94 & 4.69 & 2.48 & 3.19 & 3.80 & 4.24 & 4.43 & 4.46 & 3.01 & 3.86 & 2.92 \\
\hline 20 & 3.68 & 2.93 & 2.58 & 4.48 & 6.06 & 4.69 & 4.86 & 4.95 & 4.18 & 4.03 & 3.81 & 2.95 & 4.02 & 2.51 & 2.69 \\
\hline 21 & 4.11 & 3.97 & 4.96 & 4.53 & 6.34 & 4.57 & 3.65 & 4.88 & 4.10 & 3.88 & 3.49 & 2.76 & 3.93 & 2.50 & 2.59 \\
\hline 22 & 2.99 & 4.61 & 4.02 & 4.17 & 0.00 & 0.00 & 4.85 & 3.10 & 2.57 & 3.66 & 3.42 & 2.74 & 3.88 & 2.48 & 2.66 \\
\hline 23 & 4.12 & 2.11 & 2.39 & 4.31 & 0.00 & 0.00 & 2.10 & 2.55 & 2.67 & 4.74 & 3.99 & 3.63 & 5.45 & 5.86 & 2.98 \\
\hline 24 & 2.74 & 2.87 & 2.71 & 1.67 & 0.00 & 0.00 & 4.21 & 3.71 & 4.06 & 4.75 & 4.20 & 3.60 & 5.46 & 5.80 & 7.45 \\
\hline 合許 & 100 & 100 & 100 & 100 & 100 & 100 & 100 & 100 & 100 & 100 & 100 & 100 & 100 & 100 & 100 \\
\hline
\end{tabular}

ずれも電力需要調整契約に加入しており，契約の種類が時刻変動 に影響していると考えられる。Cパターンは各期とも一般的な午後 のピーク時間帯から外れている。D パターンは各期とも変動幅が最 も小さく, 蓄熱効果が見られる。E パターンは変動幅が大きく, 夜 間のピークが昼間を上回る点で $\mathrm{B}$ パターンとは対照的である。 D パ ターンの夏期と $\mathrm{E}$ パターンの各期では, 深夜の $23 \sim 1$ 時にピーク を迎えており, 電力需要調整契約による夜間へのピークシフトが顕 著に見られる。

\section{4 過去と現在のエネルギー消費の比瞻}

冷蔵倉庫 No.8, No.10, No.21, No.34, No.38については, 1967 年度に同様の電力消費量調査を行っている。以下, 同一施 設の過去（1967 年年度）注10 と現在（1999 年度）のデータを用い て，エネルギー消費の変化について分析を行った。

表8に各冷蔵倉庫の収容能力及び年間電力使用量を示す。収 容能力についてみると, すべての泠蔵倉庫で増加している。特に 增加率の高いNo.34とNo.38 はいずれもR3 グループに属し, 収 容能力が $90 \%$ 前後増加し, 年間電力使用量もそれぞれ増加して いるが，年間電力使用量原単位をみるといずれも減少している。一 方, 収容能力で約3割増加したNo.10（R2 グループ）とNo.21（R3 グループ）は，年間電力使用量，原単位ともに減少している。No.8 は, 同じR2 グループの No.10 と同規模であるが, 収容能力の増 加率が他に比べて低いにも関わらず, 年間電力使用量, 原単位 ともに $40 \%$ 以上増加している。

以上のように, No. 8 以外の冷蔵倉庫では，年間電力使用量の 増減に関わらず原単位が減少している。これについては以下のよ うな説明が考えられる。

No.8 とそれ以外の冷蔵倉庫の違いは，収容能力の増加率であ る。前者の収容能力は微増に留まっているのに対し，後者は約 30 \%以上増加している。№. 8 の建物は, 調査を行った 2000 年度の 時点では未改修で, 冷蔵倉庫会社によると, 年間電力使用量を削 减するため，次年度以降に全面改修もしくは建替する計画を検討
中とのことであった。また冷凍機械設備は，平成6年にアンモニア 冷凍設備からフロン冷凍設備に変更済みであったが, 年間電力使 用量は，平成 9 年度に $1224 \mathrm{MWh} /$ 年，平成 10 年度に $1247 \mathrm{MWh} /$ 年, 平成 11 年度に $1295 \mathrm{MWh} /$ 年と漸增しており, 冷凍機の効率 向上を上回るほどの熱需要が生じていると考えられる。熱需要の増 加には，保管品の入出庫頻度や年間総取扱量なども影響している と考えられるが， 30 年以上前の該当データは入手が困難なため定 量的に確認できない。一方，泠蔵倉庫会社によると，近年の年間 総取扱量はほぼ横ばいである上，冷蔵車の能力向上により入庫さ れる保管品の温度管理が適切に行われているため, 各入庫時に 温度上昇を抑えるための泠却は少なくなっているとのヒアリング結果 がある。以上から，保管品の入出庫頻度や年間総取扱量などが年

衰 8 過去（1967年年度）と現在（1999年度）の比較

\begin{tabular}{|c|c|c|c|c|}
\hline 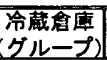 & 比䡆項目 & $\begin{array}{c}\text { 過丢 } \\
1967 \text { 年度 }\end{array}$ & $\begin{array}{c}\text { 現在 } \\
1999 \text { 年度 }\end{array}$ & 增加率 \\
\hline \multirow{3}{*}{ No.8 } & 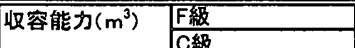 & 8,750 & 9,000 & \\
\hline & 荛部 & 8.750 & 9,000 & $3 \%$ \\
\hline & 湅結能力(t/日) & 0 & 0 & \\
\hline \multirow[t]{2}{*}{ (R2) } & 年間電力使用兾(kWh/年) & 882,114 & $1.295,178$ & $47 \%$ \\
\hline & 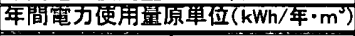 & 100.81 & 143.91 & \\
\hline \multirow[b]{3}{*}{ No.10 } & \begin{tabular}{|l|l|} 
収容能力 $\left(\mathrm{m}^{3}\right)$ & F級 \\
\end{tabular} & 8,604 & 8,605 & \\
\hline & C級 & & 2,301 & \\
\hline & 合訲 & 8,604 & 10,906 & 2780 \\
\hline \multirow{3}{*}{ (R2) } & 湅結能力 $(t / \theta)$ & & 20 & \\
\hline & 年間電力便用量(kWh/年) & $1,258,415$ & $1,203,091$ & $-4 \%$ \\
\hline & 年間電力便用畐原單值 $(\mathrm{kWh} /$ 年・解 $)$ & 146.26 & 110.31 & $-25 \%$ \\
\hline \multirow{2}{*}{ No.21 } & \begin{tabular}{|l|l|} 
收容能力 $\left(\mathrm{m}^{3}\right)$ & F級 \\
\end{tabular} & 32,907 & 42,290 & \\
\hline & \begin{tabular}{|l} 
C級 \\
Aft $^{\text {f }}$
\end{tabular} & 329 & & \\
\hline \multirow{3}{*}{ (R3) } & 阑結能力(t/日) & & $\frac{42,290}{10}$ & 296 \\
\hline & 年間電力使用量(kWh/年) & $2,978,500$ & $2,308,311$ & $-23 \%$ \\
\hline & 年間䉓力便角畐原單位 $\left(\mathrm{kWh} /\right.$ 年 $\left.\cdot \mathrm{m}^{3}\right)$ & 90.51 & 54.58 & $-40 \%$ \\
\hline \multirow[b]{3}{*}{ No.34 } & \begin{tabular}{|l|l|} 
収容能力 $\left(\mathrm{m}^{3}\right)$ & F級 \\
\cline { 2 - 2 }
\end{tabular} & 33,750 & 49,127 & \\
\hline & C級 & & 14,048 & \\
\hline & 合尌 & 33,750 & 63,175 & $87 \%$ \\
\hline \multirow{3}{*}{ (R3) } & 谏結能力(t/日) & & 30 & \\
\hline & 年間電力使用量(kWh/年) & $3,340,538$ & $4,627,969$ & 398 \\
\hline & 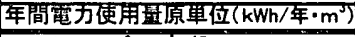 & 98.98 & 73.26 & $-26 \%$ \\
\hline \multirow{5}{*}{ (R3) } & 收容能力 $\left(\mathrm{m}^{3}\right)$ F級 & 27,399 & 53,260 & \\
\hline & 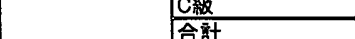 & 27399 & $\frac{0}{53260}$ & 948 \\
\hline & 阑結能力(t/日) & & & \\
\hline & 年間電力使用量(kWh/年) & $2,307,500$ & $3,971,712$ & 728 \\
\hline & 年間電力使用量原單位 $(\mathrm{kWh} /$ 年 & 84.22 & & \\
\hline
\end{tabular}


表 9 過去（1967 年年度）と現在（1999年度）の月別比較

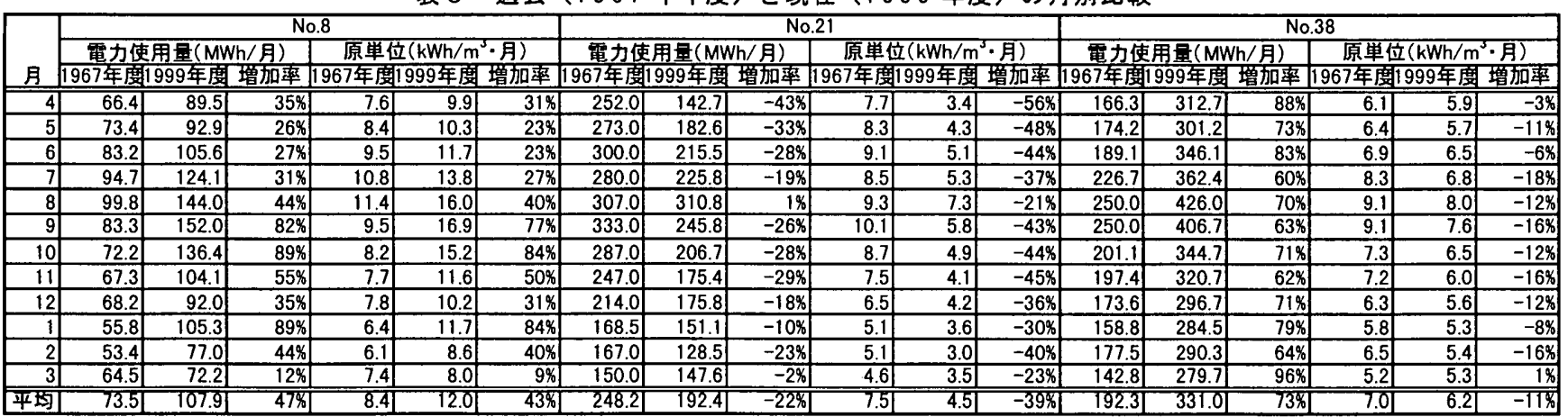

間電力使用量の増加の主要因ではないと考えられる。よって No.8 は，建物の大規模改修が行われていないために断熱性の向上を 望めない点が年間電力使用量の増加に影響していると考えられる。

その点, No.8 以外については, 収容能力の増加規模から大規 模改修や設備更新が行われたと考えられ，結果的に建物の断熱性 が向上したため，荷捌室のクローズド化による外気流入量の減少， 冷凍車の能力向上による保管品温度の保温, 過去数十年で促進 された冷凍機設備の効率向上などが相乗効果が順当に反映され て，電力使用量原単位の減少をもたらしたと考えられる。

また, No.10とNo.21 を比較すると収容能力の増加率がほぼ同 程度であるのに対し，No.21の方が年間電力使用量及び原単位の 減少率が高い。要因については以下のような説明が考えられる。

収容能力の内訳を見ると，No.10の増加分はC級であるが， No.21 はF級であることがわかる。また，No.10 は電力需要調整契 約に未加入だが，No.21はピーク時間帯契約に加入している。F 級は保管温度帯以下に過冷却を行っても食品の品質に与える影響 が小さいが，C級は主に凍結を避けつつ鮮度を保つ目的で保管さ れる食品を扱うので, 保管品の品質管理上, 過泠却は適さない。 一方, 電力需要調整契約では, 夜間に過冷却を行い, 冷室内の 保管品を熱媒として蓄熱効果を図っている。よって, C級よりもF 級 が増加する方が, 電力需要調整契約による蓄熱効果が期待でき, 年間電力使用量及び原単位の減少に繋がっていると考えられる。

さらに, No.8, No.21, No.38を取り上げ, 各冷蔵倉庫の月別 電力消費について分析を行う。各冷蔵倉庫の月別電力使用量及 び月別電力使用量原単位を図 18 〜図 20, 表9に示す。

No. 8 の年間電力使用量は $43 \%$ 増加しており，図 18 から特に 8 〜 11月を中心に増加していることがわかる。原単位も同時期に増 加しているが, 電力使用量に比べると増加率は低い。一方, No.21 の年間電力使用量は $23 \%$ 減少しており，図 19 から特に中間期に 大きく減少していることがわかる。原単位は年間で $40 \%$ 減少し，夏 期の減少率は比較的低いが中間期には $40 \%$ 以上減少している。 No.38の年間電力使用量は $72 \%$ 増加しているが，夏期の増加率 は他の時期に比較すると低く，No.8における夏期の増加率に比べ ても低く抑えられている。原単位は年間で $11 \%$ の減少，夏期の 3 ヶ 月には平均 $15 \%$ の減少がみられる。

No. 8 は電力需要調整契約に未加入であるが, No. 21 , No. 38 は いずれもピーク時間調整契約に加入している。前述の通り，電力 需要調整契約により夜間へのピークシフトが促進されるため, 電力

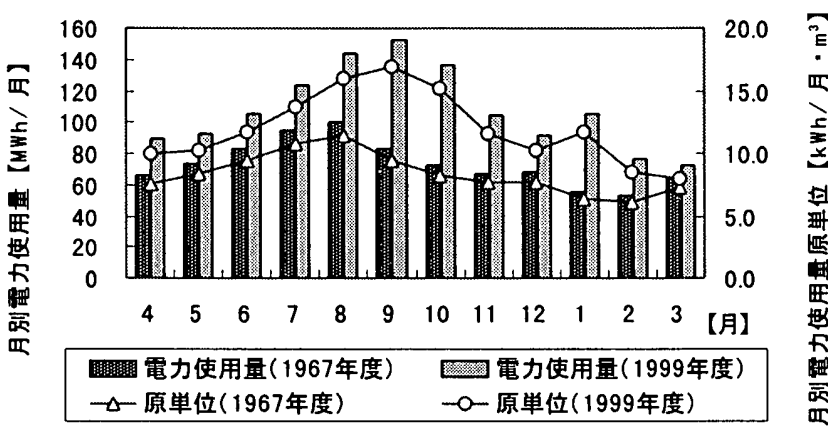

図 18 現在と過去の比較（No.8）

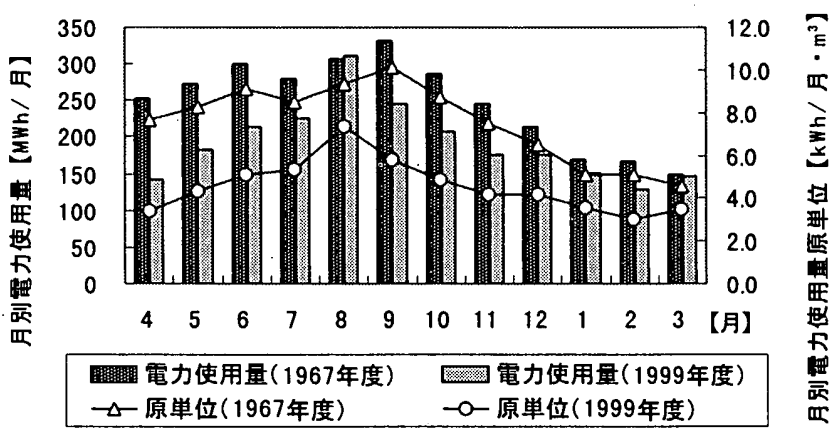

図 19 現在と過去の比較（No.21）

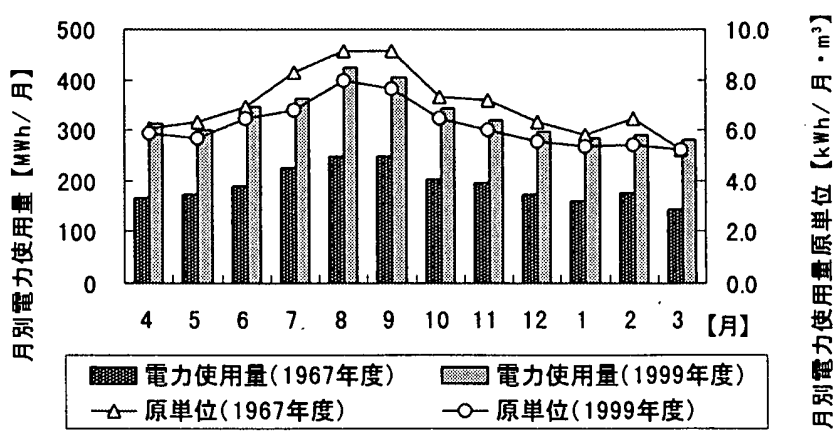

图 20 現在と過去の比較（No.38）

使用量が日中の外気温変動に左右されにくく，夏期，中間期にお ける電力使用量の削減に慗がっていると考えられる。

\section{5 他の建物用途との年間エネルギー消費量原単位の比較}

図 21 において，泠蔵倉庫の年間エネルギー消費量原単位(一 次エネルギー換算【MJ/ $\mathrm{m}^{2}$ ・年】）の変化注 11 を他の建物用途と比 較した6)。比較対象としては，一般オフィスビルとデパート注 12 を取り 上げた。過去のデータを見ると, 冷蔵倉庫の年間エネルギー消費 量原単位は一般オフィスビルの約 1.5 倍に相当しているが, デ 
パートには及ばない。現在のデータをみると，冷蔵倉庫 R5 グルー プが一般オフィスビルと同等程度になるが， R2 R $4, \mathrm{R} 6$ グルー プは一般オフィスビルの3分の1以下の值に相当する。また,一般 オフィスビルとデパートの増加に比べると，冷蔵倉庫の年間エネル ギー消費量原単位は减少傾向にあることがわかる。

\section{5. 総括及ひ今後の展望}

本研究の成果は，以下の7点にまとめられる。

1)冷蔵倉庫は，立地別に特性が分かれることが明らかになった。 港湾型は件数が多く，市場型や内陸型に比べると大規模で，主に 冷凍需要に対応しており，電力需要の制御を積極的に行っている。 対照的に，市場型は小口貨物の冷蔵需要に対応している。

2)冷蔵倉庫のエネルギー消費を立地別の特性を考虑して分析し た結果，6つの原単位グループに分かれた。立地の他に取容能 力, 製水能力，産業用蓄熱調整契約等の項目がエネルギー消费 に影響していることが明らかになった。

3)原単位グループ別に年間電力使用量原単位を比較した結果, 製水機能を持つグループは，持たないグループに比べて 3 倍以上 高いことがわかった。また収容能力の大きい冷蔵倉庫ほど年間電 力使用量原単位が低く抑えられていることから，年間電力使用量原 単位は，冷蔵倉庫の規模に反比例する傾向にあることが明らかに なった。

4)原単位グループ別に月別電力使用量原単位を比較した結果, 製水ありのグループは夏期のピークに冬期の約 2 倍に，それ以外 のグループの約 $4 \sim 5$ 倍に相当する。また他のグループは年間を 通じて変動幅が小さいことがわかった。

5)時刻別の電力使用量は，需要調整契約への加入状況により 異なるパターンになることを考慮し，時刻別電力使用量原単位を分 類した。需要調整契約に加入しているパターンは，夜間の消費割 合が高く, 加入していないパターンに比べると時刻変動が小さいこ とがわかった。

6)同一施設について 1967 年度と 1999 年度に行われた調查デー 夕を比較した結果，全体的に収容能力が増加しているのに対し， 年間電力使用量は増加するケースと減少するケースがあるが, 電力 使用量原単位は堿少していることが明らかになった。一方，建物の 老朽化によるエネルギー効率の低下を示唆するケースもみられた。

7)他の建物用途と年間エネルギー消費量原単位の変化を比較し た結果，泠蔵倉庫は減少傾向にあることがわかった。

近年，都市に㧊いてオフィスや住宅のエネルギー需要が増加の 一途を辿る中で，冷蔵倉庫等の大規模な需要源におけるエネル ギー消費の効率化を図る意義は大きい。本研究の結果， 30 年前 に比較して概ね効率の向上が確認できたが，建物の老朽化が進 む今後は，より一層確実な方策を求めていく必要がある。今後の施 設更新にあたっては，その立地を考虑の上，エネルギー供給形態 を含めた対策が検討されることを期待する。

\section{倸辞}

本研究における冷蔵倉庫の実態調査にご協力頂きました日本冷蔵倉庫協会及び 各冷藏倉庫の関係者の皆様に深く感謝致します。また調査データの実測・分析 に力を貸してくれた研究室メンバーの皆椂,ご協力有㖵うございました。

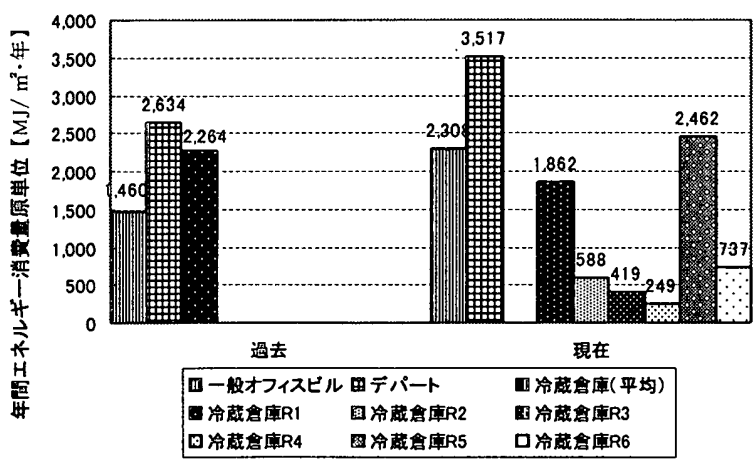

\section{图 21 他の用途との年間エネルギー消費量原単位の比皎}

注

注1)1967年及び1968年に早稲田大学尾島俊雄研究室が都区部の冷蔵倉庫28 件を対象に行った実態調查を指す。尾島俊雄, 建築の光熱水費, 丸善株式会 社，1984，p.78-82 に記载。

注2)本調查の一理として行ったヒアリング結果に基つく。ヒアリングは, 2000年8〜 9月にかけて社団法人日本冷蔵倉庫協会, 立地の異なる複数の泠蔵倉庫を保 有する冷蔵合蓮を対象に, 冷蔵倉庫の概要を把握するために行った。

注3)C級と同様，F級についても保管温度帯別に表記することが本来望ましいが， 本調查ではF級の保管温度帯別データが入手できなかった為, F級全体として 表記している。

注4)製水能力とは，1日あたりに生産可能な氷の量 $(\mathrm{t} /$ 日)を表す。一般に，製 氷能力 $1(\mathrm{t} /$ 日) は日本冷凍トン $1.72(J R T)$ に相当するとされている。

注5)凍結能力とは，1日あたりに凍結可能な食品の些 $(\mathrm{t} /$ 日)を表す。ここで凍 結とは, 食品の初期温度から最大水結晶生成帯(食品の水分が凍り始めてから その大部分が凍り終わる温度帯: $\left.-1^{\circ} \mathrm{C} \sim-5^{\circ} \mathrm{C}\right)$ を速やか通過し, 食品の中心 温度がー $18^{\circ} \mathrm{C}$ 以下に下がるまで椧却する加工作業のことをいう。

注6)電力会社は, 工場など高圧・特別高压電力の契約主に対し，主に付帯契 約で遇用できる選択約款により，安価な夜間電力の有効利用を衔め，夏期の 午後に生じ電力需要のピークカットを図っている。

注7)冷蔵會庫No.40とNo.41は, 港湾区域及び港湾隣接地域に建設された椧 蔵倉庫ではないが, 港湾隣接地域と隣接しているので便宜上港湾型とする。 注8)原単位は, 冷蔵目庫全体の電力使用蛋(荷捌室や事務室も含む)を収容容 稓で割って算出した

注9)夏期とは $7 \cdot 8 \cdot 9$ 月を，中間期とは $3 \cdot 4 \cdot 5 \cdot 6 \cdot 10 \cdot 11$ 月を，冬期とは $12 \cdot 1 \cdot 2$ 月を指す。

注 10)尾島俊雄，建築の光熱水费，丸善株式会社, 1984，p.129-130，p.181185，その他調査原データより 1967 年度の調查データを引用した。

注 11)過去については，尾島俊雄，建筑の光熱水費，丸善株式会社，1984， p.181-182 に記载の 1967 年のデータを用いた。現在については，ここまで 延床面積あたりのデータを扱っていない上，実態調査では延床面皘のデータを 入手できなかったため，以下の方法で延床面稳あたりの原単位を算出した。 よって笄密な値ではない。まず, 表 $8 に$ に記载の椧蔵倉庫について, 1967年度 の収容能力 $\mathrm{A}\left(\mathrm{m}^{3}\right)$ と建築延休面積 $\mathrm{B}\left(\mathrm{m}^{2}\right)$ のデータから係数 $(\mathrm{A} / \mathrm{B})$ を求め, 平均値を取り $0.5196\left(\mathrm{~m}^{2} / \mathrm{m}^{3}\right)$ を得た。これを 1999 年度の収容能力に乗してて 建築延休面積を算出し年間電力使用量をこれで割った。

注12)参考文献6に記载のデータを引用した。過去については, 一般オフィスビ ル（10階以下の事務所ビル）は，1995 年〜 1985 年，デパートは 1976 年 のデータを，現在については，それぞれ1986 年〜1993 年，1990年〜1991 年のデータを用いた。

\section{考文献}

1)社団法人日本淪蔵倉車協会, 冷蔵倉庫業界レポート1999, p. 2 より。 2)社団法人日本椧蔵倉車協会, 冾蔵合庫業界レポート1999, p.4より。 3)社団法人日本冷蔵倉庫協会, 営業椧蔵倉庫の機能と物流サービス, http:// www.jarw.or.jp/guide_f.html，2001より。

4)東京冷蔵倉庫協会, 協会紹介, http://www.toreiso.gr.jp/about.html, 2001 上り。

5)社団法人日本冷藏合庫協会，冷蔵倉庫業界レポート1999，p.5より。 6)尾島俊雄研究室, 建築の光熱水原単位 [東京版], 早稲田大学出版部, 1995 年, p.29-33 (一般オフィスビル) p.72-75（デパート）より。

（2002年 2 月 10 日原稿受理，2002年11月 12 日採用決定） 